\title{
Mechanism of noradrenaline influence on the secretion of ovarian oxytocin and progesterone in conscious cattle
}

\author{
D. Skarzynski and J. Kotwica* \\ Division of Animal Reproduction, Endocrinology and Pathophysiology, Centre for Agrotechnology and \\ Veterinary Sciences, Polish Academy of Sciences, 10-718 Olsztyn-Kortowo, PO Box 55, Poland
}

Noradrenaline stimulates the concomitant release of ovarian oxytocin and progesterone in cattle within a few minutes, but the mechanism of its action is unknown. Changes in $\alpha$ - and $\beta$-receptors and blood pressure were considered as possible mechanisms of the noradrenaline effect. Heifers in group $1(n=4)$ were infused with noradrenaline $\left(0.16 \mu \mathrm{g} \mathrm{kg}^{-1} \mathrm{~min}^{-1}\right)$ for $30 \mathrm{~min}$ into the aorta abdominalis (cranial to the origin of the ovarian artery) on day 10 . On days 11 and 12 before noradrenaline, phentolamine ( $\alpha$-blocker; $30 \mu \mathrm{g} \mathrm{kg}^{-1} \mathrm{~min}^{-1}$ ) or propranolol $\left(\beta\right.$-blocker; $5 \mu \mathrm{g} \mathrm{kg}^{-1} \mathrm{~min}^{-1}$ ) were infused for $30 \mathrm{~min}$. Four other heifers were infused with noradrenaline only as controls. Only propranolol inhibited the stimulatory effect of noradrenaline on the secretion of progesterone and oxytocin. In group 2, heifers $(n=4)$ were infused, making use of the latin square design, with vasoconstrictive (angioten$\sin ; 0.042 \mu \mathrm{g} \mathrm{kg}^{-1} \mathrm{~min}^{-1}$ ) or vasodilatory (xanthinol-theophyline nicotinate; $250 \mu \mathrm{g} \mathrm{kg}^{-1}$ $\left.\min ^{-1}\right)$ drugs that do not act through the adrenoceptors. Noradrenaline $\left(0.3 \mu \mathrm{g} \mathrm{kg}^{-1} \mathrm{~min}^{-1}\right)$ was given I h later as in group I. Blood pressure changes were measured in the posterior aorta abdominalis and oxytocin and progesterone concentrations were determined in the blood samples collected from the jugular vein. Noradrenaline and angiotensin increased $(P<0.01)$, whereas xanthinol decreased $(P<0.01)$, blood pressure during their infusion. However, the rise of oxytocin and progesterone concentrations was observed only after noradrenaline infusion. We suggest that (i) noradrenaline enhances the secretion of progesterone and oxytocin from the corpus luteum acting through $\beta$-receptors; and (ii) increase of vascular blood pressure which does not occur concomitantly with $\beta$-receptor stimulation does not appear to be involved in the corpus luteum secretion.

\section{Introduction}

Noradrenaline injected into the aorta abdominalis stimulates the secretion of ovarian oxytocin and progesterone in heifers (Kotwica et al, 1991a), but not if the same dose is infused into the jugular vein (Kotwica et al., 1990). Noradrenaline is therefore considered to act locally upon the ovary. However, the nature of this effect is unknown. The response of granulosa cells to noradrenaline challenge measured by oxytocin or progesterone secretion in studies in vitro was observed after a few days (Luck and Jungclas, 1987). It was therefore suggested that such prompt secretion of ovarian hormones in experiments in vivo may partly depend upon noradrenaline action through the vascular adrenoceptors and blood pressure changes. This contention is supported by studies by Heap et al. (1989), who found that noradrenaline caused a rapid release of oxytocin in ewes, closely associated with ovarian blood flow reduction, probably via vascular bed $\alpha$ receptors (Reynolds and Ford, 1984). This hypothesis was verified in the present paper.

\section{Materials and Methods}

\section{Animals and surgical procedure}

Mature heifers of Black and White breed (350-450 kg body weight) with regular oestrous cycles were synchronized by means of a PGF $2 \alpha$ analogue $(500 \mu \mathrm{g}$; Oestrophan, Spofa). The onset of oestrus was taken as day 0 . A catheter was inserted into the posterior aorta abdominalis through the coccygeal artery (Kotwica et al., 1990) on day 10 for infusion of either saline or drugs. The tip of this cannula was positioned cranially to the origin of the ovarian artery. Consequently, the infused drugs could be transported by the bloodstream directly into the reproductive tract. A jugular vein was cannulated for the collection of blood. Furthermore, in Expt 2, heifers had one more catheter placed in the posterior aorta abdominalis through the dorsal costoabdominal artery (Haibel et al., 1989) for measurement of blood pressure.

\section{Preliminary experiments}

Kotwica et al. (1990, 1991a) found that $4 \mathrm{mg}$ of noradrenaline given for $30 \mathrm{~min}\left(0.3 \mu \mathrm{g} \mathrm{kg} \mathrm{gin}^{-1}\right)$, which is a therapeutic 
dose recommended for humans, was very effective at stimulating the corpus luteum in cattle if it was given into the aorta abdominalis but not if it was infused into the jugular vein. In the study reported here noradrenaline was infused after treating heifers with $\alpha$ - or $\beta$-blockers; we wanted to avoid the criticism that the dose of noradrenaline used could overcome the effect of adrenoceptor blockers. Four different doses of noradrenaline ( $1,2,3$ or $4 \mathrm{mg}$ ) were therefore infused in four different heifers on day 10 of the oestrous cycle.

The doses of drugs that did not act on blood vessels through adrenoceptors were determined by infusing a heifer for $30 \mathrm{~min}$ with either $0.5,1.0$ or $2.0 \mathrm{mg}$ of angiotensin (Hypertensin, Ciba-Geigy, Switzerland) and another heifer was infused with either 2, 3, or $4 \mathrm{~g}$ of xanthinol (Sadamin, Polfa) in the next preliminary experiment. Heart rate and blood pressure were recorded via a catheter inserted into the dorsal costoabdominal artery.

\section{Experiment 1}

Four heifers from group 1 were infused with saline and noradrenaline on day 10 and then in latin square design on days 11 and 12 of the oestrous cycle, and were given phentolamine ( $\alpha$-blocker; $30 \mu \mathrm{g} \mathrm{kg}^{-1} \mathrm{~min}^{-1}$ ) or propranolol ( $\beta$-blocker; $5 \mu \mathrm{g} \mathrm{kg}^{-1} \mathrm{~min}^{-1}$ ) for $30 \mathrm{~min}$ and then $2 \mathrm{mg}$ of noradrenaline also for $30 \mathrm{~min}$. Every subsequent noradrenaline infusion causes a lower secretion of oxytocin (Skarzynski et al., 1991; Kotwica and Skarzynski, 1993), in accordance with the proposal that once the synthesized peptide has been released this store cannot be replenished by synthesis de novo (Ivell, 1987), but only by using prohormone pools. Four other heifers (group 2) were therefore infused on day 10,11 and 12 with saline and this was followed by noradrenaline as in group 1 . Concentrations of oxytocin and progesterone in these heifers served as control values and were compared with those in group 1 .

\section{Experiment 2}

Four heifers were infused for $30 \mathrm{~min}$ on days 11 and 12 , using the latin square design, with vasoconstrictive $(0.5 \mathrm{mg}$ angiotensin i.e. $\left.0.042 \mu \mathrm{g} \mathrm{kg}^{-1} \mathrm{~min}^{-1}\right)$ or vasodilatory $(3.0 \mathrm{~g}$ xanthinol; $250 \mu \mathrm{g} \mathrm{kg}^{-1} \mathrm{~min}^{-1}$ ) drugs. One hour after the infusion of drug was terminated, $2 \mathrm{mg}$ of noradrenaline was given as in group 1. Blood pressure changes in the posterior aorta abdominalis were recorded and oxytocin and progesterone concentrations in the plasma of blood collected from jugular vein were determined every 5-10 min.

\section{Hormone determination}

Oxytocin and progesterone were determined as described by Schams et al. (1979) and Kotwica et al. (1990), respectively. Ovine progesterone antiserum (GDN No 337, kindly donated by G. D. Niswender, Colorado) was characterized as described by Gibori et al. (1977) and rabbit oxytocin antiserum (R-I, donated by G. Kotwica) showed less than $0.01 \%$ crossreactivity with arginine-vasopressin, lysine-vasopressin, angiotensin, vasotocin and somatostatin (Sigma, Deisenhofen). Sensitivity of the assay averaged $0.3-0.6 \mathrm{ng} \mathrm{ml}^{-1}$ for progesterone and $3 \mathrm{pg} \mathrm{ml}^{-1}$ for oxytocin. The coefficients of correlation between added and
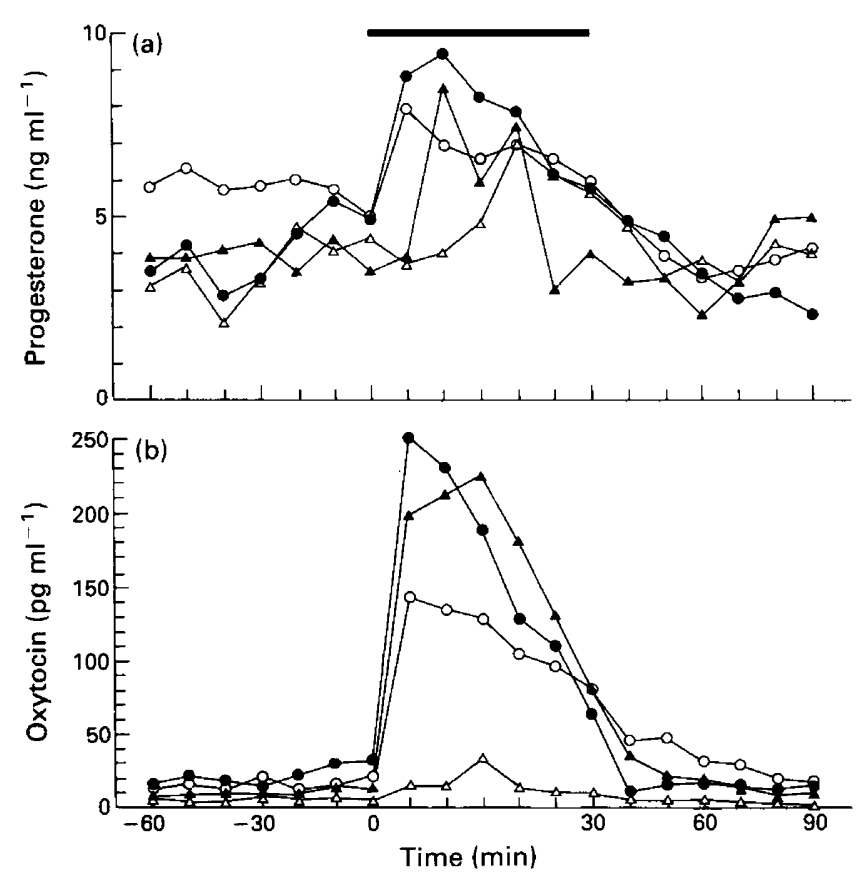

Fig. 1. Plasma (a) progesterone and (b) oxytocin before, during $(\longrightarrow$ and after infusion of different doses of noradrenaline (O) $4 \mathrm{mg}(\boldsymbol{\Delta})$ $3 \mathrm{mg}(O) 2 \mathrm{mg}(\triangle) 1 \mathrm{mg}$ into the aorta abdominalis in one heifer on day 10 of the oestrous cycle.

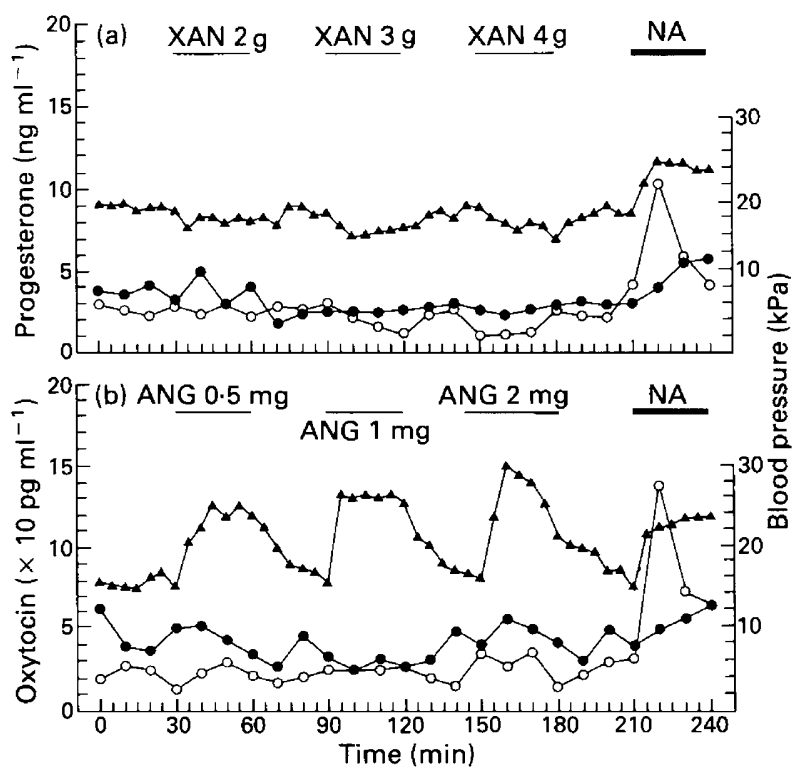

Fig. 2. Influence of different doses of (a) xanthinol (XAN) in one heifer and (b) angiotensin (ANG) in another heifer infused into the aorta abdominalis on the peripheral concentrations of progesterone (O), oxytocin $(\mathrm{O})$ and arterial blood pressure $(\mathbf{A})$. One hour after the final infusion of each drug, $4 \mathrm{mg}$ of noradrenaline (NA) was infused. Horizontal bars illustrate drug infusion lasting $30 \mathrm{~min}$ each. 


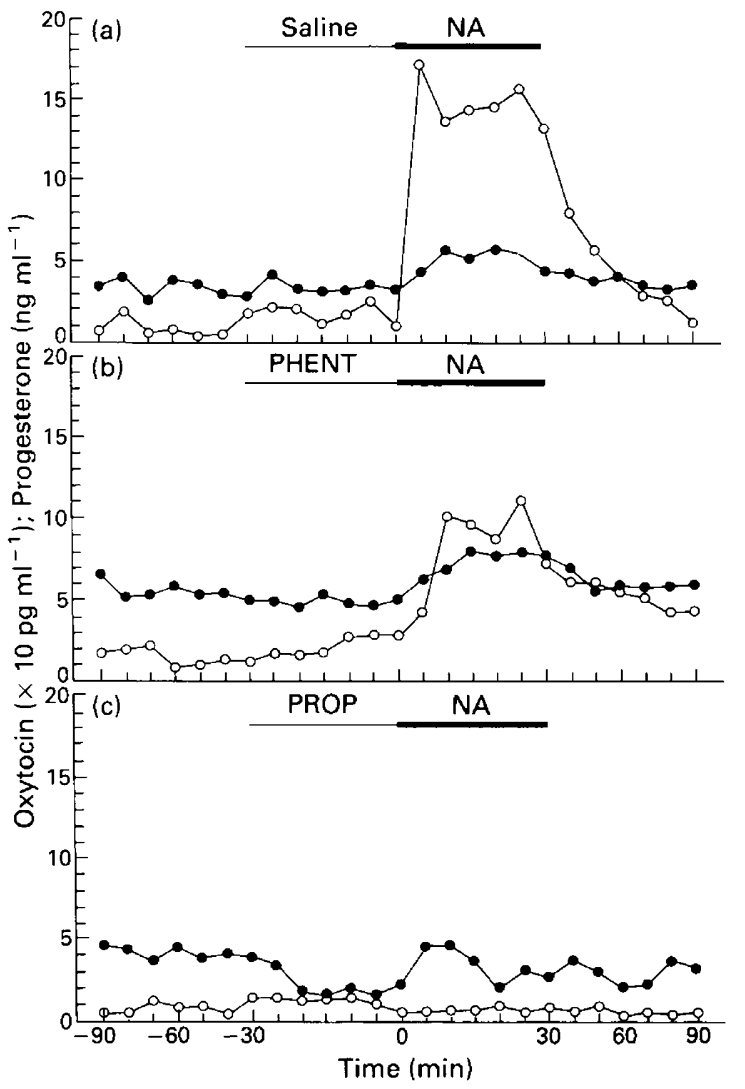

Fig. 3. Effect of noradrenaline (NA; $2 \mathrm{mg}$ ) infused into the aorta abdominalis of one representative heifer pretreated with (a) saline, (b) phentolamine (PHENT; $30 \mu \mathrm{g} \mathrm{kg}^{-1} \mathrm{~min}^{-1}$ ) and (c) propranolol (PROP; $5 \mu \mathrm{g} \mathrm{kg}^{-1} \mathrm{~min}^{-1}$ ) on day 10,11 and 12 respectively, on the peripheral concentrations of progesterone $(O)$ and oxytocin $(O)$.

recovered amounts of progesterone and oxytocin in plasma for four different concentrations were 93 and $95 \%$, respectively. Intra- and interassay coefficients of variation were 9.6 and $20.2 \%$ for progesterone and 5.6 and $10.5 \%$ for oxytocin, respectively, and depended on hormone concentrations.

\section{Statistical analysis}

Mean values of hormones for each period of blood sampling during treatment were compared with the previous concentration by a one-way analysis of variance, to estimate the time of the significant rise in the concentration of a hormone after treatment. The areas under the curves of oxytocin and progesterone concentrations were calculated during treatment with xanthinol, angiotensin and noradrenaline. Differences between mean values $( \pm$ SEM) were estimated by one-way analysis of variance.

\section{Results}

\section{Preliminary experiments}

There was a dose-dependent effect of noradrenaline on oxytocin and progesterone release $(P<0.01)$ (Fig. I). The dose of $2 \mathrm{mg}$ of noradrenaline was therefore chosen for further studies.
Infusion of the highest dose of angiotensin was interrupted owing to a violent rise of blood pressure from $16.5 \mathrm{kPa}$ of up to $24.0 \mathrm{kPa}(180 \mathrm{~mm} \mathrm{Hg}$ within a few minutes and it rose continuously). The doses of $0.5 \mathrm{mg}$ angiotensin and $3 \mathrm{mg}$ xanthinol were therefore chosen for further studies (Fig. 2).

\section{Experiment 1}

Noradrenaline given after pretreatment of heifers with saline or phentolamine $(\alpha$-blocker) stimulated $(P<0.01)$ the secretion of both progesterone and oxytocin within a few minutes. Only propranolol given before noradrenaline infusion prevented its stimulatory effect (Fig. 3; Table 1). Furthermore, the comparison of oxytocin and progesterone concentrations stimulated by noradrenaline on days 10-12 after adrenoceptor blockers to those after saline on the same days (Fig. 4) showed that hormone concentrations were significantly lower only after propranolol pretreatment (Table 1).

\section{Experiment 2}

Basal values of blood pressure were in the range 16.0$17.3 \mathrm{kPa}(120-130 \mathrm{~mm} \mathrm{Hg})$. Infusion of heifers with angiotensin increased blood pressure from a basal value of $16.0-17.3 \mathrm{kPa}$ up to $24.0-24.7 \mathrm{kPa}(P<0.01)$, whereas xanthinol decreased blood pressure by $17-25 \%$ to $13.0-13.3 \mathrm{kPa}$ during treatment $(P<0.05)$. The increase of blood pressure caused by noradrenaline infusion was similar $(P>0.05)$ to that shown by angiotensin. In spite of these blood pressure changes, only noradrenaline could stimulate oxytocin and progesterone secretion significantly (Table 2; Fig. 5).

\section{Discussion}

A prompt response of oxytocin and progesterone to noradrenaline challenge was observed in this study and in earlier work (Kotwica et al., 1991a), contrary to the response of granulosa cells to catecholamines which lasts for hours or even days in an in vitro system (Luck and Jungclas, 1987). We have previously assumed (Kotwica et al., 1991a) that the response was caused by the direct action of noradrenaline on blood vessels and on myofibrils of smooth ovarian muscles. However, present data showed that the blood pressure changes lasting for a short period, without simultaneous activation of luteal $\beta$-receptors, had no influence on the secretory function of the corpus luteum (Table 2; Figs 2 and 5). The increase in blood pressure caused by angiotensin even produced a transient decrease of progesterone release (Table 2). The early corpus luteum is devoid of innervation (Bahr et al., 1974; Burden, 1978) but essential ingrowth of adrenergic nerves is observed during the luteal phase in humans (Hamberger et al., 1980) and is suggested to be associated with the formation of blood vessels in the developing corpus luteum. However, sympathetic denervation of the rat ovary does not influence ovarian blood flow (Gibson and Roche, 1986). However, since noradrenaline (Battista et al., 1987; Heap et al., 1989; Kotwica et al., 1991a) and B-mimetics (Condon and Black, 1976; Wheeler et al., 1988; Kotwica et al., 1991b) influence the secretion of the corpus luteum, we suggest 
Table 1. Progesterone and oxytocin concentrations above the baseline in the peripheral blood (area under the curve; mean \pm SEM) during infusion of noradrenaline ( $2 \mathrm{mg}$ for $30 \mathrm{~min}$ ) on days 10,11 and 12 in heifers pretreated in latin square design with saline, phentolamine or propranolol and in control heifers pretreated with saline only

\begin{tabular}{llccc}
\hline & & \multicolumn{3}{c}{ Days of oestrous cycle } \\
\cline { 3 - 5 } Hormone & \multicolumn{1}{c}{ Group } & 10 & 11 & 12 \\
\hline Progesterone & $\begin{array}{l}\text { Experimental } \\
(n=4)\end{array}$ & $3.24 \pm 0.60$ & $4.48 \pm 1.17$ & $0.51 \pm 0.30^{*}$ \\
Oxytocin & $\begin{array}{l}\text { Control } \\
(n=4)\end{array}$ & $3.46 \pm 0.70$ & $4.02 \pm 0.40$ & $5.60 \pm 1.40$ \\
& $\begin{array}{l}\text { Experimental } \\
(n=4)\end{array}$ & $18.35 \pm 1.95$ & $11.32 \pm 1.27$ & $1.05 \pm 0.67^{*}$ \\
$\begin{array}{l}\text { Control } \\
(n=4)\end{array}$ & $18.53 \pm 2.34$ & $9.72 \pm 1.50$ & $9.85 \pm 1.25$ \\
\hline
\end{tabular}

"Value significantly different from control $(P<0.001)$

Number of heifers given in parentheses.

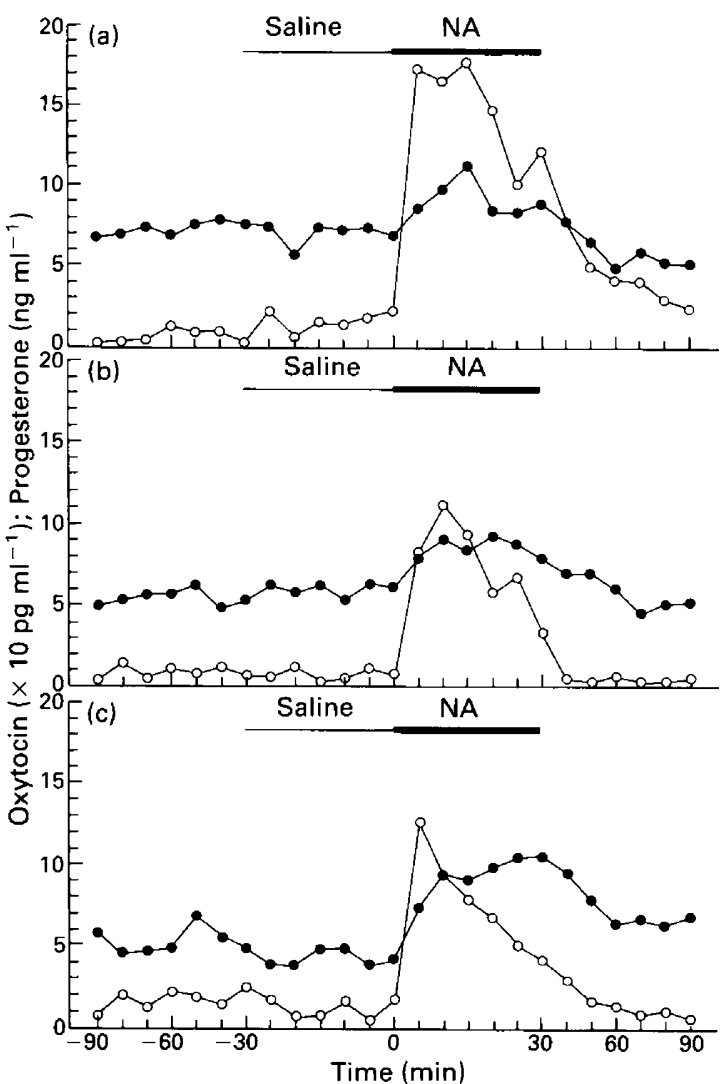

Fig. 4. Influence of noradrenaline $(2 \mathrm{mg}$ ) infused into the aorta abdominalis ( $\longrightarrow$ of one representative heifer on days (a) 10, (b) 11 and (c) 12, pretreated on each day with saline only (horizontal line) on the peripheral concentrations of progesterone $(0)$ and oxytocin $(O)$.

that the main role of ovarian sympathetic innervation is to act directly upon the secretory part of the ovary and thus modify its function. Data by Martensson and Carter (1982) and by

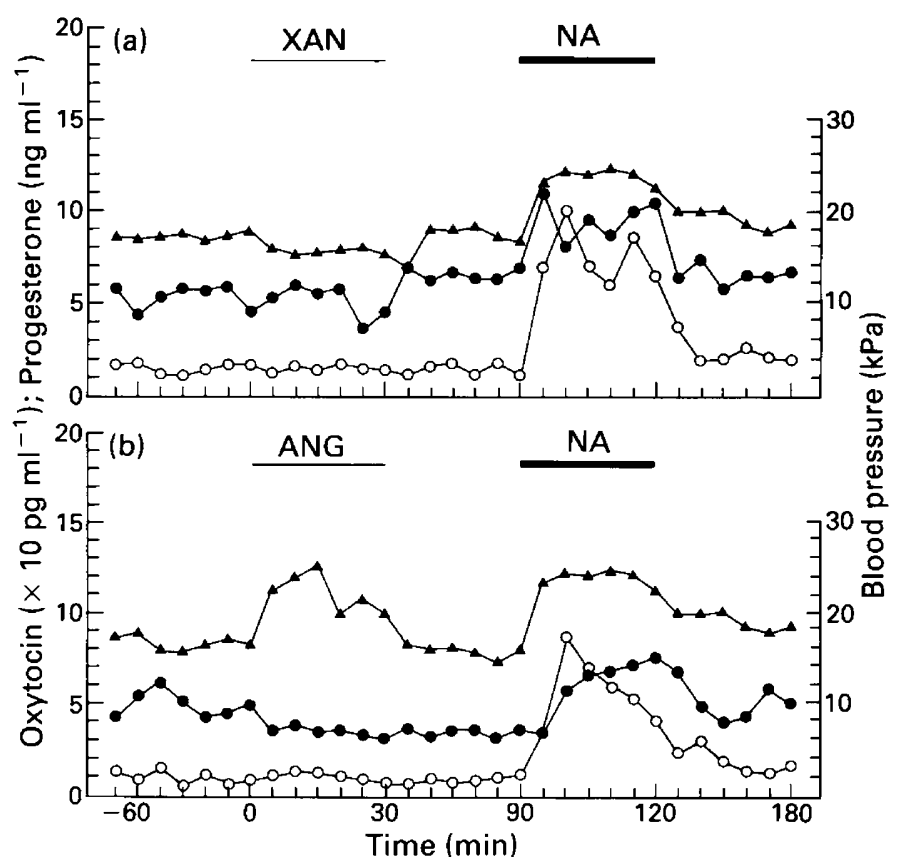

Fig. 5. Concentrations of oxytocin $(O)$ and progesterone $(O)$ in peripheral blood and blood pressure $(\boldsymbol{\Delta})$ measured in the castoabdominal artery during infusion of (a) vasodilatory (xanthinol: XAN; $3 \mathrm{~g}$ ) or (b) vasoconstrictive (angiotensin: ANG; $0.5 \mathrm{mg}$ ) drug, followed with $4 \mathrm{mg}$ of noradrenaline (NA). Each drug was infused for $30 \mathrm{~min}$ (horizontal bar).

Wiltbank et al. (1990), who found that blood vessels of the corpus luteum do not undergo autoregulation, support this view. Taking into account the early stages of corpus luteum formation and its importance in early pregnancy, this mechanism protects and even supports the normal function of the corpus luteum regardless of blood pressure changes in the general circulation. This seems to be crucial, especially in stressful situations, in domesticated and even more importantly in wild animals, for example during the escape reaction. 
Table 2. Mean ( \pm SEM) progesterone and oxytocin concentrations above the baseline (area under the curve; $\mathrm{cm}^{2}$ ) after $30 \mathrm{~min}$ infusion of noradrenaline preinfused with angiotensin or xanthinol in latin square design on days 11 and 12

\begin{tabular}{lccc} 
Hormone & $\begin{array}{c}\text { Noradrenaline } \\
(4 \mathrm{mg})\end{array}$ & $\begin{array}{c}\text { Angiotensin } \\
(0.5 \mathrm{~g})\end{array}$ & $\begin{array}{c}\text { Xanthinol } \\
(3 \mathrm{~g})\end{array}$ \\
\hline Progesterone & $7.2 \pm 2.9$ & $-2.62 \pm 1.0$ & 0 \\
Oxytocin & $9.0 \pm 2.4$ & $0.28 \pm 0.26$ & 0 \\
\hline
\end{tabular}

Noradrenaline is involved in LH secretion (Parvizi and Ellendorff, 1982) which is luteotrophic in cattle (Hoffman et al., 1974). However, this was not the case in this study, as the dose of drug infused into the aorta abdominalis did not influence the secretion by the ovary if it was given systemically (Kotwica $e t$ al., 1990). Furthermore, LH concentrations were unchanged if measured in blood samples collected from heifers in preliminary experiments during noradrenaline infusion, compared with the pretreatment period (J. Jaroszewski and J. Kotwica, unpublished). This result confirms our assumption that the dose of noradrenaline used exerts a local effect upon the corpus luteum. Isoproterenol ( $\beta$-mimetic) stimulates progesterone secretion in small but not in large luteal cells (Niswender et al, 1985), suggesting that $\beta$-receptors occur primarily on small cells. Furthermore, small but not large cells also seem to possess specific receptors for oxytocin (Niswender et al., 1985; Miyamoto and Schams, 1991). Thus in the present experiment noradrenaline stimulated the $\beta$-receptors of the small cells, but caused the release of oxytocin, which is synthesized in large luteal cells (Guldenaar et al., 1984; Fields et al., 1992). We do not know the identity of the signal sent from small to large cells that evokes release of oxytocin simultaneously with progesterone or even before that. Nevertheless we assume that consideration of cell-to-cell communication is crucial for further understanding of the mechanism of noradrenaline influence on the secretory function of the bovine corpus luteum.

Hirst et al. (1986) found that depolarization of cells in luteal slices with excess potassium or supplementation of medium with calcium or calcium ionophore caused a rapid onset of oxytocin secretion. These data indicate that oxytocin release is calcium dependent, which is consistent with the exocitoic release of this hormone. It is possible that intracellular products of luteal cells like insulin-like growth factor 1 , insulin or prostaglandins (Schams et al., 1988; McArdle and Holtrof, 1989; McArdle 1990), which are affected by noradrenaline, are involved in these processes.

In conclusion, we suggest that (i) constant sympathetic stimulation causes activation of $\beta$-adrenoceptors of luteal cells by noradrenaline and through cAMP mediation (Lefkowitz and Caron, 1987) influences the basal progesterone secretion (Kotwica et al., 1991b); (ii) during short-term stress, activation of luteal $\beta$-receptors by noradrenaline seems to be amplified by its simultaneous influence on blood pressure that may be attributed to large increases in blood flow to the corpus luteum (Wiltbank et al., 1990) allowing the use of serum-derived lipoprotein as a source of cholesterol for steroidogenesis (Grummer and Caroll, 1988).
This research was supported by grant from MR/USDA-92-94. We thank G. D. Niswender (Colorado State University, Fort Collins, USA) for progesterone antiserum and G. Kotwica (University of Agriculture and Technology, Olsztyn, Poland) for oxytocin antiserum. We are indebted to Z. Skowronski (Ciba-Geigy, Warsaw) for hypertensin donation and S. Niedzwiedzki and B. Niedzwiedzka for excellent cooperation.

\section{References}

Bahr J, Kao L and Nalbandov AV (1974) The role of catecholamines and nerves in ovulation Biology of Reproduction 10 273-290

Battista PJ, Poff JP, Deaver DR and Condon WA (1987) Biogenic amine regulation of bovine luteal progesterone production in vivo Joumal of Reproduction and Fertility 80 517-522

Burden HW (1978) Ovarian innervation. In The Vertebrate Ovary pp 615-638 Ed. RE Jones. Plenum Press, New York

Condon WA and Black DL (1976) Catecholamine-induced stimulation of progesterone by the bovine corpus luteum in vitro Biology of Reproduction 15 573-578

Fields MJ, Barros CM, Watkins WB and Fields PA (1992) Characterization of large luteal cells and their secretory granules during the estrous cycle of the cow Biology of Reproduction 46 535-545

Gibori G, Antczak E and Rotchild I (1977) The role of oestrogen in the regulation of luteal progesterone secretion in the rat after day 12 of pregnancy Endocrinology 100 1483-1495

Gibson WR and Roche PJ (1986) Blood flow in the ovary and oviduct of rats after sympathetic denervation Joumal of Reproduction and Fertility 78 193-199

Grummer RR and Caroll DJ (1988) A review of lipoprotein cholesterol metabolism: importance to ovarian function Journal of Animal Science 66 3160-3173

Guldenaar SEF, Wathes DC and Pickering BT (1984) Immunocytochemical evidence for the presence of oxytocin and neurophysin in the large cells of the bovine corpus luteum Cell and Tissue Research 237 349-352

Haibel GK, Guilbault LA, Villeneuve P and Thatcher WW (1989) Aortic catheterization in cattle via the costoabdominal artery and validation for progesterone and estradiol-17 $\beta$ sample collection American Joumal Veterinary Research 50 1923-1925

Hamberger L, Denefors B, Hamberger B, Janson PO, Nilsson L, Sjogren A and Wiquist N (1980) Is vascular innervation a prerequisite for PG-induced luteolysis in the human corpus luteum? In Advances in Prostaglandin and Thromboxane Research Vol. 8 pp 1365-1368 Eds B Samuelsson, PW Ramwell and R Paoletti. Raven Press, New York

Heap RB, Fleet IR, Davis AJ, Goode JA, Hamon MH, Walters DE and Flint APF (1989) Neurotransmitters and lymphatic-vascular transfer of prostaglandin $F_{2}$ stimulate ovarian oxytocin output in sheep Joumal of Endocrinology $\mathbf{1 2 2}$ $147-159$

Hirst JJ, Rice GE, Jenkin G and Thorburn GD (1986) Secretion of oxytocin and progesterone by ovine corpora lutea in vitro Biology of Reproduction 35 1106-1114

Hoffman B, Schams D, Bopp R, Ender ML, Gimenez T and Karg H (1974) Luteotrophic factors in the cow: evidence for LH rather than prolactin Journal of Reproduction and Fertility 40 77-85

Ivell $\mathbf{R}$ (1987) Vasopressinergic and oxytocinergic cells: models in neuropeptide gene expression. In Neuropeptides and their Peptidases pp 31-64 Ed. WH Turner. Ellis Horwood Ltd, Chichester, and VCH, Weinheim

Kotwica J and Skarzynski D (1993) Influence of oxytocin removal from the corpus luteum on secretory function and duration of the oestrous cycle in cattle Joumal of Reproduction and Fertility 97 411-417

Kotwica J, Skarzynski D and Jaroszewski J (1990) Coccygeal artery as a route for the administration of drugs into the reproductive tract of cattle Veterinary Record 127 38-40

Kotwica J, Skarzynski D, Jaroszewski J and Kotwica G (1991a) Effect of norepinephrine on the release of progesterone and ovarian oxytocin in cattle Animal Reproduction Science 26 179-191

Kotwica J, Skarzynski D and Jaroszewski J (1991b) Involvement of $\beta$ adrenoceptors in the regulation of luteal function in cattle British Veterinary Joumal 147 189-196

Lefkowitz RJ and Caron MG (1987) Molecular and regulatory properties of adrenergic receptors Recent Progress in Hormone Research 43 469-497

Luck M and Jungclas B (1987) Catecholamines and ascorbic acid as stimulators of bovine ovarian oxytocin secretion Journal of Endocrinology 114 423-430 
McArdle CA (1990) Chronic regulation of ovarian oxytocin and progesterone release by prostaglandins: opposite effects in bovine granulosa and early luteal cells Journal of Endocrinology 126 245-253

McArdle CA and Holtrof A-P (1989) Oxytocin and progesterone release from bovine corpus luteal cells in culture: effects of insulin-like growth factor I, insulin, and progesterone Endocrinology 124 1278-1286

Martensson L and Carter AM (1982) Effect of norepinephrine on circulation in the genital tract of early and late pregnant guinea-pigs Joumal of Reproduction and Fertility $6623-29$

Miyamoto A and Schams D (1991) Oxytocin stimulates progesterone release from microdialysed bovine corpus luteum in vitro Biology of Reproduction $\mathbf{4 4}$ 1163-1170

Niswender GD, Schwall RH, Fitz TA, Farin CE and Sawyer HR (1985) Regulation of luteal function in domestic ruminants: new concepts Recent Progress in Hormone Research 41 101-151

Parvizi N and Ellendorff F (1982) Further evidence on dual effects of norepinephrine on LH secretion Neuroendocrinology 35 48-55
Reynolds LP and Ford SP (1984) Contractility of the ovarian vascular bed during the oestrous cycle and early pregnancy in gilts Journal of Reproduction and Fertility 71 65-71

Schams D, Schmidt-Polex B and Kruse V (1979) Oxytocin determination by radioimmunoassay in cattle Acta Endocrinologica 92 258-270

Schams D, Koll R and Li CH (1988) Insulin-like growth factor-I stimulates oxytocin and progesterone production by bovine granulosa cells in culture Joumal of Endocrinology 116 97-100

Skarzynski D, Pesta M and Kotwica J (1991) Influence of oxytocin removal from corpora lutea on the length of the oestrous cycle in cattle Journal of Reproduction and Fertility Abstract Series 8 Abstract 90

Wheeler AG, Lean J and Walker M (1988) Peripheral progesterone concentrations in the luteal-phase ewe: effects of a $\beta$-adrenergic receptor antagonist and two $\beta_{2}$-adrenergic agonists Journal of Endocrinology 116 137-142

Wiltbank MC, Gallagher KP, Christensen AK, Brabec RK and Keyes PL (1990) Physiological and immunological evidence for a new concept of blood flow regulation in the corpus luteum Biology of Reproduction 42 139-149 